\title{
Quantification of environment-driven changes in epiphytic macroinvertebrate communities associated to Phragmites australis
}

\author{
Miguel CAÑEDO-ARGÜELLES* and Maria RIERADEVALL \\ F.E.M. (Freshwater Ecology and Management) research group, University of Barcelona. Diagonal 645. 08028 Barcelona \\ *e-mail corresponding author: mcanedo-arguelles@ub.edu
}

\begin{abstract}
The epiphytic macroinvertebrate communities associated with the Common Reed, Phragmites australis (Cav.) Trin. ex Steudel, were examined seasonally from summer 2004 to spring 2005 in eleven coastal lagoons of the Llobregat Delta (NE Spain) following the method proposed by Kornijów \& Kairesalo (1994). The aims of the study were to: 1) characterise and quantify changes in epiphytic macroinvertebrate communities along environmental gradients; 2) assess the contribution of elements of the epiphytic compartment to structuring the community; 3) define the optima and tolerances of selected epiphytic macroinvertebrate taxa for the most relevant ecological factors responsible for assemblage composition; and 4) identify possible epiphytic species assemblages that would allow a lagoon's typology to be established, as well as their representative indicator species. Communities showed statistically significant seasonal variation, with two faunal peaks: one in summer, with high chironomid densities, and the other in winter, with high naidid densities. These peaks showed a clear response to the influence of environmental factors. Salinity explained the highest percentage of total variance (36\%), while trophic variables (nutrients, phytoplanktonic chlorophyll-a, and total organic carbon) and epiphyton biomass (19.2 and 4\% of total variance explained, respectively) were secondary. Three different epiphytic macroinvertebrate species assemblages could be defined. These assemblages were directly linked to conductivity conditions, which determined the rate of survival of certain taxa, and to the existence of a direct connection with the sea, which permitted the establishment of "brackish-water" species. In spite of the existence of these species assemblages, the species composition and biomass of epiphytic macroinvertebrates and epiphyton differed substantially between lagoons; both elements were subject to changes in the environment, which finally determined the site-to-site variation in the density and composition of the macroinvertebrate population.
\end{abstract}

Key words: chironomids, coastal lagoons, transitional waters, common reed, species optima and tolerances

\section{INTRODUCTION}

Emergent helophytes are a common element of lentic systems, creating littoral habitat structures (Jayawardana et al. 2006) that support diverse algal and faunal communities (Batzer et al. 1999; Scheffer 2004). These littoral structures, taken as a whole, form a differentiated compartment in the water consisting of three main elements: i) the host plant, ii) the epiphyton, understood as the complex community of microbiota that is attached to macrophytes (Wetzel 1983), and iii) the associated macroinvertebrates (Fig. 1). These elements are known to be tightly linked, and the interactions between them have been the subject of several studies (Papas 2007).

i) The host plant plays an important role for aquatic macroinvertebrates. It serves as a site for oviposition and a refuge against predators (Rooke 1984; Scheffer 2004). It also provides food sources for these invertebrates (Urban 1975; Kornijów et al. 1990), which can consume the plant directly or ingest the accumulated organic matter and detritus in the litter around helophyte stands (Bedford et al. 2005), although these food source pathways have been proven to be less significant than attached epiphytic algae in terms of quantity and assimilation efficiency
(Hart \& Lovvorn 2003). The host plant also provides the substrate for epiphyton growth, which can influence the plant through direct competition for carbon and light (Jones et al. 2002).

ii) Epiphyton growth is mainly controlled by grazing epiphytic macroinvertebrates (Mason et al. 1975; Cattaneo 1983; Lodge 1985; Brönmark 1989; Hann 1991; Botts 1993; Wetzel 2005) and by the availability of light (Müller 1995; Wellnitz et al. 1998; Bourassa et al. 2000) and nutrients (Havens et al. 1999; Pan et al. 2000; Maberly et al. 2002; Liboriussen 2003).

iii) Epiphytic macroinvertebrate communities are shaped by the characteristics of the habitat created by the plant and the epiphyton, which is a direct food source for them (Fig. 1). These communities are also subjected to changes in the environment related to seasonal trends (Kairesalo 1984; Botts et al. 1993; Löhlein 1996), water level fluctuations (Balcombe et al. 2007), and differences in the physicochemical composition of the water (Kornijów et al. 1990; Arnold et al. 1997; Sahuquillo et al. 2006; Sahuquillo et al. 2007). Environmental factors influence macroinvertebrates both directly (the organisms show different tolerances to salinity and pollution) and indirectly (the environment exerts an influence over the host plant and the epiphyton, leading to 


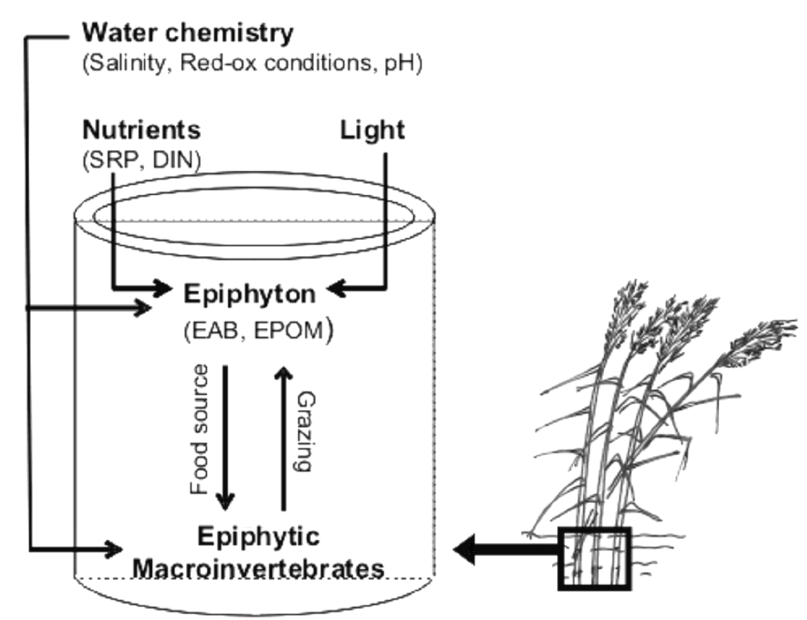

Fig. 1. Idealized scheme of the main elements in the epiphytic compartment. Arrows and attached text indicate the way of the relation among elements. $(\mathrm{DIN}=$ Dissolved Inorganic Nitrogen; $\mathrm{EAB}=$ Epiphytic Algae Biomass; EPOM = Epiphytic Particulate Organic Matter; SRP = Soluble Reactive Phosphorous).

changes in the epiphytic macroinvertebrate communities).

Since most studies have focused on understanding specific interactions between certain elements of the epiphytic compartment, the response of the communities to environmental conditions on a broader scale remains poorly understood. Furthermore, there are very few quantitative studies concerning the epiphytic macroinvertebrate communities associated with helophytes, and these have been carried out in just one sampling site (Kornijów et al. 1990; Kornijów et al. 1992; Botts et al. 1993; Löhlein 1996) or on a single sampling occasion (Sahuquillo et al. 2006).

In the present study, we took into consideration the fact that each plant species supports different invertebrate assemblages (Rooke 1984; Cattaneo et al. 1998; Taniguchi et al. 2003) according to its physical and biological characteristics (Papas 2007). Accordingly, the study focused exclusively on one plant species to avoid distorting the effects of environmental factors on the macroinvertebrate fauna (Sahuquillo et al. 2007). The Common Reed, Phragmites australis (Cav.) Trin ex Steudel, was selected because it has a wide ecological tolerance (Chambers et al. 1999) (allowing us to collect samples along a large environmental gradient); is present in the littoral zones of waters all around the world in both cold and tropical regions (Den Hartog et al. 1989); and is easy to sample quantitatively (Kornijów et al. 1994).

As a wide range of environmental conditions could be needed to identify the main factors shaping communities, the coastal lagoons of the Llobregat Delta plain offered an interesting frame for this purpose. They form a very heterogeneous and dynamic ecosystem mainly controlled by the mixing of freshwater and seawater and the action of various anthropogenic forces, which take place at short distances between sites and within the same biogeographical unit. Our main objectives were to: 1) characterise and quantify changes in the epiphytic macroinvertebrate communities along environmental gradients; 2) assess the contribution of the elements of the epiphytic compartment on structuring the community; 3) define optima and tolerances of selected epiphytic macroinvertebrate taxa for the most relevant ecological factors responsible for assemblage composition; and 4) identify possible epiphytic species assemblages that would allow a lagoon's typology to be established, as well as their representative indicator species.

\subsection{Study area}

Although the water bodies of the Llobregat Delta plain are located close together, they are isolated from each other and represent very different environmental conditions, influenced mainly by the mix of highly enriched freshwater discharges and seawater inputs. The Llobregat Delta is of special interest as it represents the transitional zone between river and sea. This is a threatened environment which is home to a great diversity of animal and plant species, many of them endemic and/or seriously endangered. It is considered of international importance by the European Union because of its role as a transition refuge for many bird species during migrations. It is situated in the northeast Iberian Peninsula (41 ${ }^{\circ} 16^{\prime}$ $41^{\circ} 25^{\prime} \mathrm{N}$ latitude and $1^{\circ} 58^{\prime}-2^{\circ} 10^{\prime} \mathrm{E}$ longitude), in Catalonia, Spain, and covers an area of $97 \mathrm{~km}^{2}$. The deltaic plain resulted from the Holocene transgression and is made up of clays, gravels, and silts that have been advancing to the sea for over 6000 years (Cabello et al. 2007). Recent works due to the expansion of the airport and the harbor of Barcelona have had drastic effects on the area. The river mouth was displaced, several bodies of water were drained, others were created, and the water circulation changed. The last census of water bodies showed that the Llobregat Delta has twenty-one 


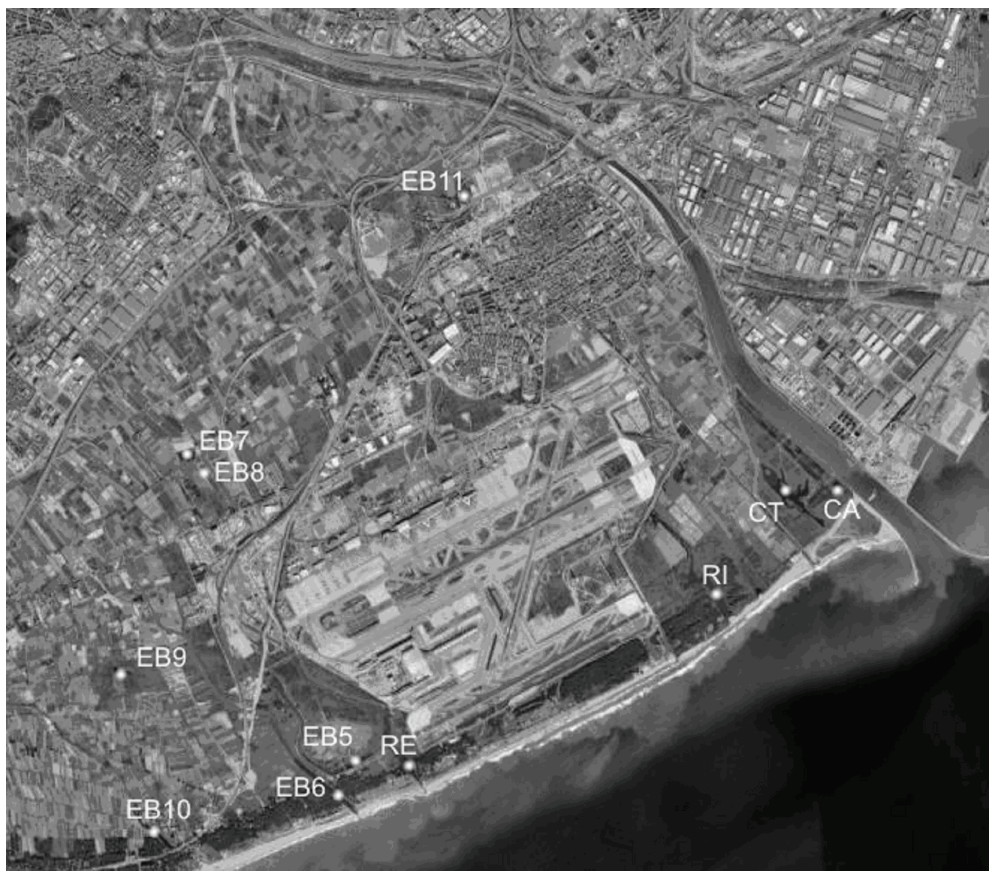

Fig. 2. Map of the Llobregat Delta (Catalonia, Spain). White dots mark the location of the examined lagoons. The airport is placed in the middle, while the new mouth of the Llobregat River is on the right side. Sites are coded as follows: CA: Ca l'Arana; CT: Cal Tet; EB5: Braç Vidala; EB6: Sant Climent; EB7: Can Dimoni Gran; EB8: Can Dimoni Petita; EB9: Reguerons; EB10: Murtra; EB11: Bassa Prat; RE: Remolar; RI: Ricarda. Satellite image source: Institut Cartogràfic de Catalunya.

lagoons, canals, and wetlands. Out of all of these water bodies, eleven were selected for the present study as they presented a well-developed helophyte belt (Fig. 2).

All the lagoons were small (areas ranging from 0.12 to $16 \mathrm{ha}$ ) and shallow (7.5 m maximum depth). Most of them were created for silt extraction, and only four of them have a natural origin (Planas 1984). They were strongly influenced by wastewater discharges from industries, urban areas, and nearby cropland. Some of them were connected with the sea, but had low water renewal rates. In some cases, like Braç Vidala and Remolar, this has led to the establishment of a permanent pycnocline, causing meromixis (Lucena et al. 2002). Reed stands were dense and formed a compact and well-delimitated ring along the shore. All the lagoons represented a monospecific emergent helophyte community of $P$. australis, except in Bassa del Prat (EB11), where Typha sp. was the dominant species.

\section{METHODS}

Epiphytic macroinvertebrates and the epiphyton layer (expressed as epiphytic organic matter and algal biomass) on $P$. australis were quantitatively sampled. Spatial and temporal heterogeneity were considered in the study by seasonally (2004-2005) collecting three different samples from each site. The geographical position and orientation of each sample was recorded to determine the influence of light exposure on the reed and, consequently, the possible effects on the development of epiphytic algae and the macroinvertebrates that fed on them (Wellnitz et al. 1998; Bourassa et al. 2000).

\subsection{Collection and identification of macroinvertebrates}

Epiphytic macroinvertebrates were collected following the method proposed by Kornijów \& Kairesalo (1994). After cutting the aerial part of some reed stems, a plastic tube $6 \mathrm{~cm}$ wide and $50 \mathrm{~cm}$ long was lowered over the stems, which were then cut with shears so that they floated up into the tube. The water was then drained out through a $250 \mu \mathrm{m}$ mesh. Macroinvertebrates were removed from the stems, placed in a tray and fixed in $4 \%$ formaldehyde. Three to ten stems were collected for each sample and their surface was measured $($ diameter $\times$ heigth $\times 3.14)$ for density calculation (individuals $\mathrm{m}^{-2}$ ).

All taxa were identified to species level when possible, except the naidid oligochaetes, which were only identified to family level. Taxon names were coded (Appendix 1), except for chironomids which followed the coding in Schnell et al. (1999).

\subsection{Biomass calculation}

The mean individual biomass of each taxon of epiphytic macroinvertebrates was obtained by selecting some individuals representative of each taxon and measuring their ash-free dry mass $\left(550{ }^{\circ} \mathrm{C}, 4\right.$ hours $)$. In the case of chironomids, because of their high abundances, instar biomasses (instars 2, 3 and 4) were weighted, using data from the literature (Prat et al. 1995) when not enough specimens were available.

Samples for estimating epiphytic algae biomass (EAB) and epiphytic particulate organic matter (EPOM) 
were collected by cutting two pieces from the submerged portion of two different stems. The pieces were washed in a plastic pot using a toothbrush and measured to allow calculation of the colonisable surface (diameter $\times$ heigth $\times 3.14)$. The attached algae were removed, and epiphytic chlorophyll- $a$ concentration was measured using spectrophotometric techniques following standard methods (Greenberg et al. 1999). This measure was converted to algal dry mass and finally to algal ash-free dry mass $(1 \mathrm{~g}$ dry mass $\approx 0.9 \mathrm{~g}$ ash-free dry mass; Benke 1996).

To measure epiphytic particulate organic matter, the samples were filtered through previously burnt Whatman GF/C filters with a pore size of $0.45 \mu \mathrm{m}$. The organic matter was calculated as the difference between the dry mass and the ash-free dry mass $\left(550{ }^{\circ} \mathrm{C}, 4\right.$ hours). Lastly, the algal and macroinvertebrate biomasses were subtracted from that measure. The resulting weight was the epiphytic particulate organic matter (EPOM).

\subsection{Physico-chemical analysis of water}

To characterise the lagoons, surface water conductivity, $\mathrm{pH}$, temperature and dissolved oxygen were measured in situ using a multi-parametric sensor (WTW, multiparameter model 197i). Transparency (Secchi disk) was also recorded in the field. Two liters of surface water were collected and kept cold until they were subjected to laboratory analysis. One liter was used for the analyses of dissolved inorganic nutrients $\left(\mathrm{NH}_{4}^{+}, \mathrm{NO}_{3}^{-}, \mathrm{NO}_{2}^{-}, \mathrm{PO}_{4}^{3-}\right.$, and $\left.\mathrm{Si}^{2+}\right)$ and total organic carbon (TOC). Suspended solids (SSP) and major ions $\left(\mathrm{SO}_{4}^{2-}, \mathrm{Cl}^{-}, \mathrm{Ca}^{2+}, \mathrm{Mg}^{2+}, \mathrm{Na}^{+}\right.$, and $\left.\mathrm{K}^{+}\right)$were also analyzed. The other liter was filtered to analyze phytoplanctonic chlorophyll- $a$. All analyses were performed following standard methods (Greenberg et al. 1999).

\subsection{Data analysis}

Prior to analysis, environmental data were normalized (logarithmic transformation) when necessary and standardized in all cases, and species abundance data were all transformed to $\ln (x+1)$. The seasonality, geographical orientation of the reed stand, and concordance between replicas within a same site were tested by performing a similarity analysis (ANOSIM) using PRIMER 6.1.2 and looking at the significance level $(p)$ and $\mathrm{R}$ statistic value (based on the difference in mean ranks between groups and within groups).

The environmental factors were grouped into components and weighted (principal components analysis, STATGRAPHICS plus 5.0) to characterise the gradient. The degree of epiphytic macroinvertebrate species turnover related to changes in the environment was assessed by performing a detrended correspondence analysis with a forward selection of environmental factors using CANOCO 4.5 (Lepš \& Šmilauer 2003). The length of the first gradient was between two and four $\left(\lambda_{1}=3.127\right)$, so a redundancy analysis (RDA) was performed to detect the main environmental factors. It provided a better explanation of the variability of the biological dataset analyzed (Legendre \& Legendre 1998), as the percentage of the explained variance in this analysis (72.4\%) was higher than in the canonical correspondence analysis (48.8\%). Variance partitioning was performed using partial redundancy analysis (pRDA) as explained in Liu (1997). The analysis was performed in order to isolate the fraction of variance in the composition of the epiphytic macroinvertebrate community that could be explained by three sets of environmental factors: water physicochemistry (conductivity, ions content, $\mathrm{pH}$ and water temperature), trophic variables (TOC, nutrient content and phytoplanktonic chlorophyll- $a$ ) and epiphyton biomass (EAB and EPOM). The range of species tolerances and their optima for the most representative environmental factors were defined performing a Weighted Average (WA) regression using C2 software (Juggins 2005). Only taxa occurring more than twice in the samples were included in the analysis.

To obtain groups of epiphytic macroinvertebrate assemblages, samples were clustered using PRIMER 6.1.2 software (2006). The percentage of similarity between samples was measured using Bray-Curtis distance, and samples with $60 \%$ similarity were grouped within the same cluster (only groups encompassing more than two samples were considered). Samples falling outside the $95 \%$ confidence limits of the sample score means were removed from analysis. Key species for each group were identified by looking at the indicator values (IV) following the method used by Dufrêne \& Legendre (1997) and using IndVal analysis with PCORD 4.20 software (McCune et al. 1999). IndVal is based on a comparison of relative abundances and relative frequencies of taxa in a priori defined site groups. Each taxon is associated with an indicator value (IV value) that varies between 0 and 100 , and a $p$-value obtained by Monte Carlo permutations (9999 runs).

\section{RESULTS}

\subsection{Environmental factors}

Principal components analysis (Fig. 3) revealed two main axes that explained $51.4 \%$ of the total environmental variance. The first axis $(29.8 \%$ of total variance explained) was related to conductivity, sulphate content, and total organic carbon, and the second axis $(21.6 \%$ of total variance explained) was related to nutrient concentration. Most sampling sites could be considered to range from mesotrophic to hypereutrophic (mean DIN values were $7.07 \pm 7.05 \mathrm{mg} \mathrm{L}^{-1}$ and mean SRP was 1.40 $\pm 1.38 \mathrm{mg} \mathrm{L}^{-1}$ ) and had mean conductivity values between 1525 and $16328 \mu \mathrm{S} \mathrm{cm}^{-1}$, with large fluctuations between seasons related to three different sources: marine water inflow, freshwater discharges, and evaporation. 


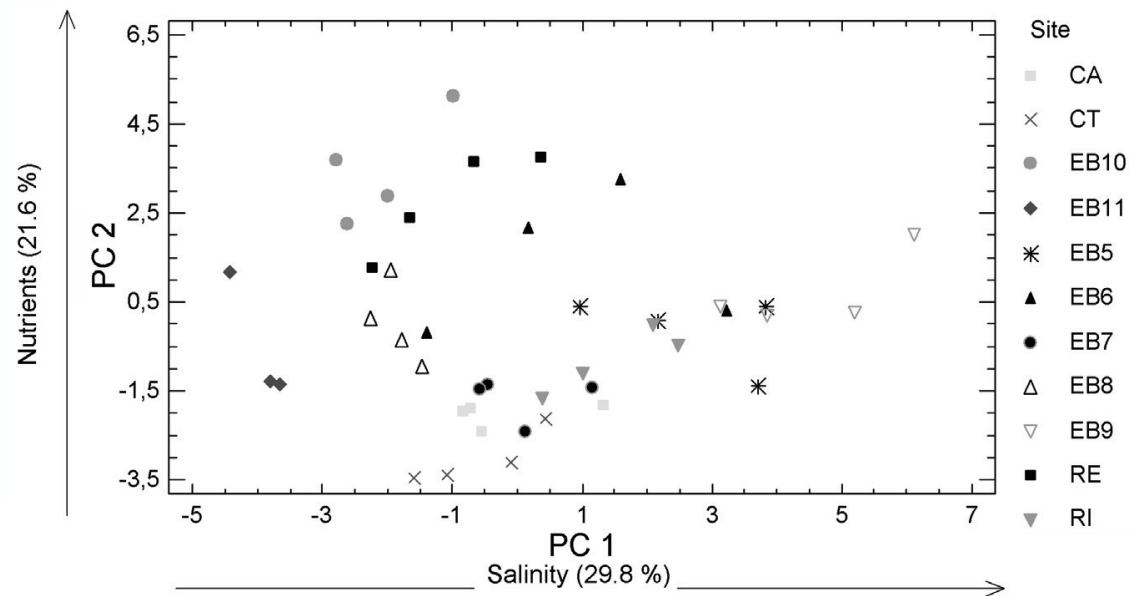

Fig. 3. Distribution of seasonal samples from lagoons in the Llobregat Delta defined by a principal components analysis with physicochemical data. Main environmental gradients identifying the axes and their percentage of total variance explained is shown by the arrows. Site codes are those in figure 2 .

\subsection{Epiphytic macroinvertebrates and epiphyton}

A total of 132 samples were processed. 30 taxa were recorded and densities ranged from 64 to 32,960 individuals $\mathrm{m}^{-2}$. Chironomids were the most diverse $(\mathrm{S}=15)$ and abundant group, averaging $79.3 \% \pm 15.1 \%$ of total density. Samples' composition was very similar within each site (ANOSIM: $p=0.001, \mathrm{R}=0.285$ ), revealing no relevant intra-lagoon variation. Neither epiphytic macroinvertebrate densities nor epiphytic algae and organic matter biomasses were influenced by the reed stand's geographical orientation $(p=0.299, \mathrm{R}=0.016 ; p$ $=0.178, \mathrm{R}=0.035$; respectively). Differences between seasons were statistically significant $(p=0.006, \mathrm{R}=$ 0.049). Macroinvertebrate densities were higher in summer and winter (mean densities were $3363 \pm 2855$ and $3719 \pm 3329$ individuals $\mathrm{m}^{-2}$, respectively) than in autumn and spring (mean seasonal values were $1153 \pm$ 646 and $2307 \pm 1193$ individuals $\mathrm{m}^{-2}$, respectively). In summer, the community was dominated by chironomids $(89.35 \pm 10.21 \%$ of total density), while in winter it was dominated by naidids ( $75.87 \pm 14.96 \%$ of total density). Detailed data on mean densities for each taxon is presented in Appendix 1.

As for the influence of different elements on the epiphytic macroinvertebrate community, water chemistry (conductivity, ion content, $\mathrm{pH}$ and temperature) was the most influential factor $(36.2 \%$ of total variance in the partial RDA), while trophic variables and epiphyton biomass were secondary (19.2\% and 4\%, respectively). The first two axes of the RDA analysis $(47.5 \%$ total variance explained) pointed out two main gradients shaping species distribution of epiphytic macroinvertebrates within the ordination space (Fig. 4), one related to conductivity and the salt content of the water bodies and the other related to their trophic state and TOC content. Coleopterans and the chironomids Chironomus riparius and Cricotopus (Isocladius) ornatus were more abundant in saline lakes with hypereutrophic waters and high TOC concentrations. Polychaetes, crustaceans, ceratopogonids, and the chironomid species Dicrotendipes pallidicornis were present in saline water bodies with lower nutrient content and high $\mathrm{pH}$ and EPOM concentrations. The chironomid species Cricotopus (Isocladius) tricinctus/trifasciatus, Cr. (I.) sylvestris and Paratanytarsus grimmi had their highest densities at hypereutrophic sites with more oligohaline waters. The rest of the taxa were present in conditions of lower conductivity and lower nutrient concentrations.

The taxa with high tolerances for both conductivity and eutrophy (high values of SRP and DIN) were the chironomids Cr. (I.) tricinctus/trifasciatus, Cr. (I.) sylvestris, Cr. (I.) ornatus and Ch. riparius (Fig. 5). The brackish-water species (sensu Cognetti and Maltagliati, 2000) Hediste diversicolor and Gammarus aequicauda, the odonate Ischnura elegans and the chironomid $D$. pallidicornis showed a high tolerance to conductivity, with an optimum over $12 \mathrm{mS} \mathrm{cm}^{-1}$. The chironomids Parachironomus and Paratanytarsus grimmi exhibited a greater tolerance for eutrophic conditions but were restricted to lower conductivity values.

Cluster analysis resulted in three groups at $60 \%$ similarity (Fig. 6), including 108 of the 113 total samples $(96 \%)$. The groups revealed three different situations related to seawater influence, which determined changes in the composition of communities and the density of epiphytic macroinvertebrates. One group of samples was from water bodies with oligohaline water rich in nitrates and the other two groups were from bodies with mesohaline water. These were differentiated by the presence or absence of direct seawater inflows; one group was from lagoons open to the sea, with higher conductivity values and lower nutrient concentrations, the other from bodies of water separated from the sea and influenced by seawater only through groundwater inflows and sea spray. 


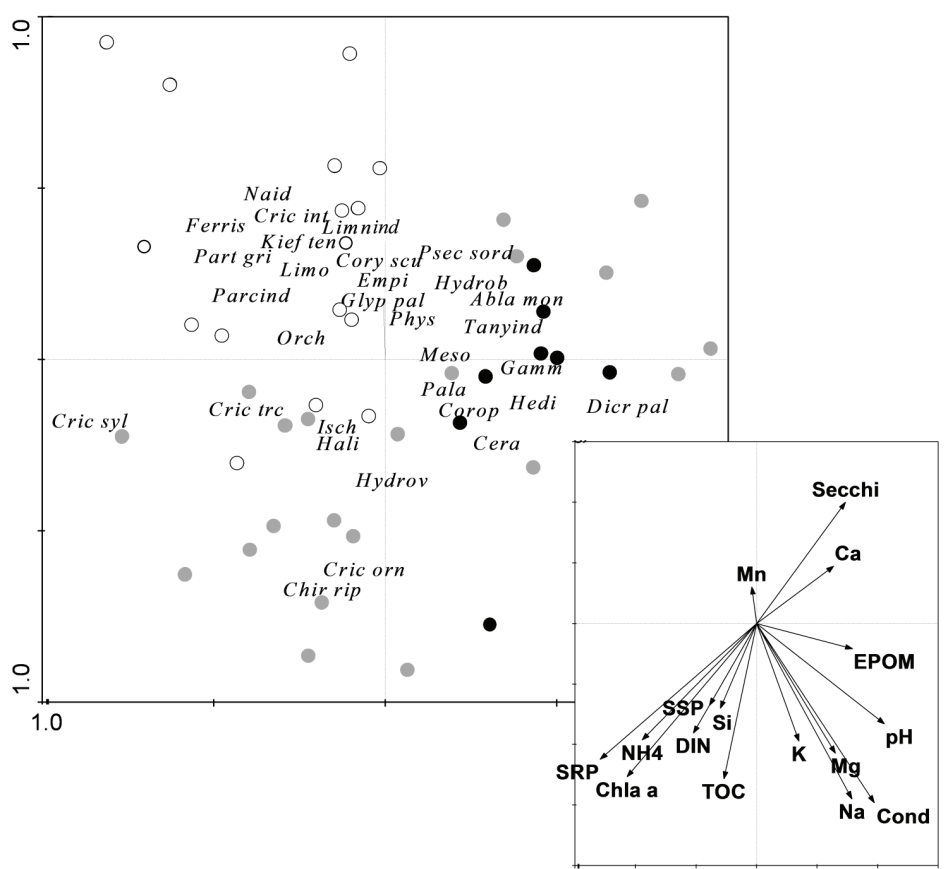

Fig. 4. Species and sites biplot in the first two dimensions of the RDA analysis. Sites are represented with circles and coloured according to the assigned group in the cluster analysis: i) black dots: Mesohaline lagoons with direct connection with the sea (MM); ii) grey dots: Mesohaline lagoons without direct connection with the sea (M); and iii) open dots: Oligohaline lagoons (O). Environmental factors and their weight in the analysis are represented in the right corner. Species codes are listed in Appendix 1.

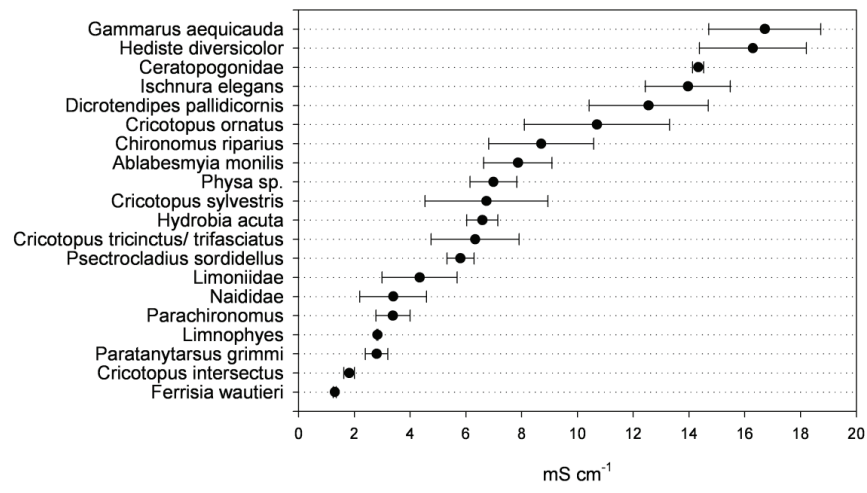

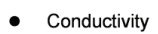

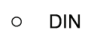

- SRP
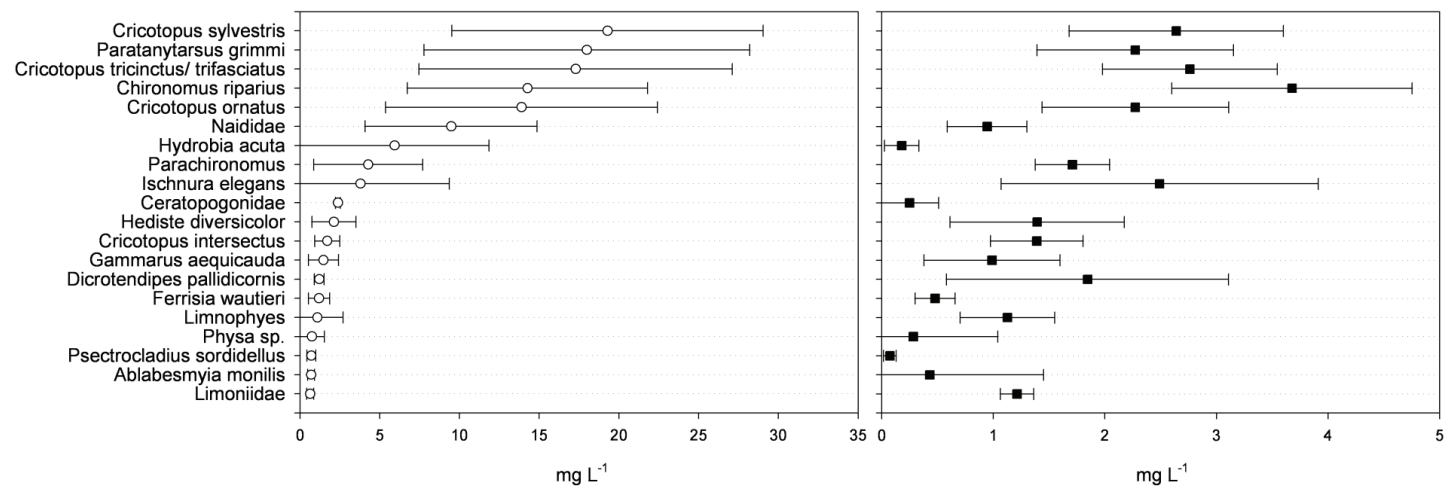

Fig. 5. Optima and tolerances of epiphytic macroinvertebrate species for the most important environmental variables according to PCA and RDA analyses. Only the taxa occurring more than twice in the samples were included in the analysis. Species are arranged according to their optima values for conductivity and for DIN. SRP = Soluble Reactive Phosphorous; DIN = Dissolved Inorganic Nitrogen $\left(=\mathrm{NH}_{4}{ }^{+}+\mathrm{NO}_{3}{ }^{-}+\mathrm{NO}_{2}{ }^{-}\right)$. 


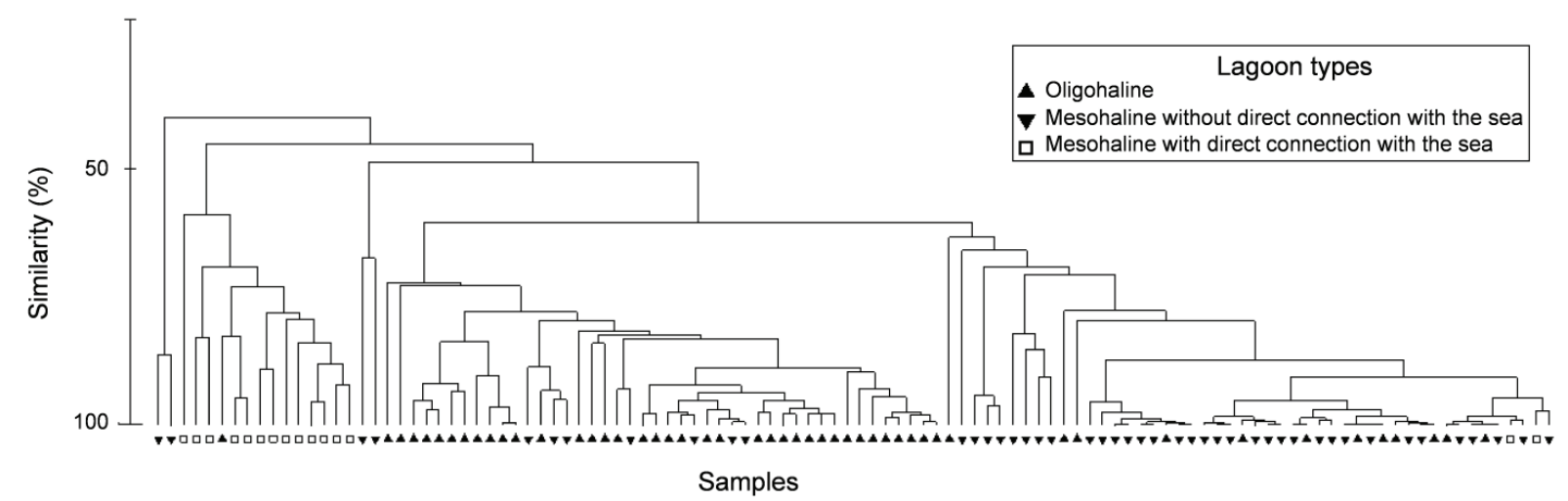

Fig. 6. Cluster analysis of epiphytic macroinvertebrate seasonal samples using Bray-Curtis distance as similarity index.

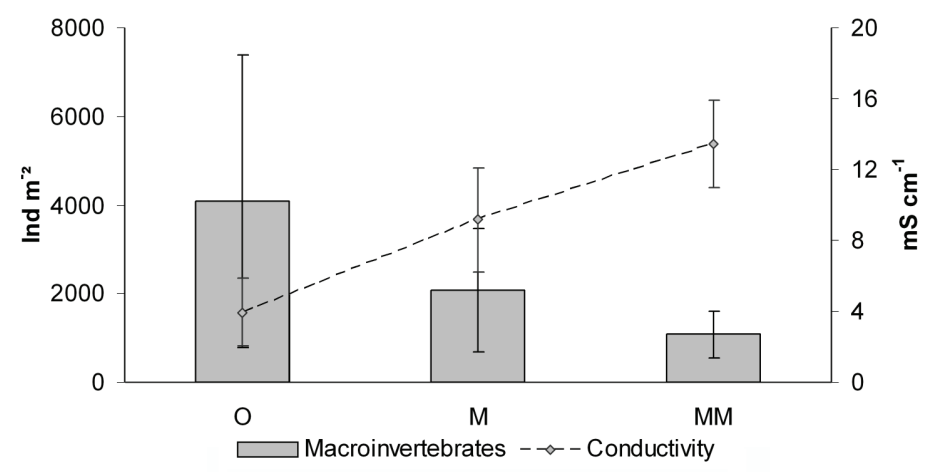

Fig. 7. Mean epiphytic macroinvertebrates' densities versus mean conductivity values of the groups resulting from cluster analysis. O = Oligohaline lagoons; $\mathrm{MM}=$ mesohaline lagoons with direct connection with the sea; $\mathrm{M}=$ mesohaline lagoons without direct connection with the sea. Standard errors are plotted.

This last group included completely confined shallow lakes and one lagoon (Remolar) where a permanent halocline was established, maintaining a nutrient-rich epilimnion and a deep layer of anoxic marine water.

The total density of macroinvertebrates decreased with increasing conductivity values when analysed across cluster groups (Fig. 7). There were also differences in EAB and EPOM biomass among the cluster groups; the mesohaline group with direct connection to the sea (MM) showed the highest biomass of both $E A B$ and EPOM, while the mesohaline group without direct connection with the sea (M) showed the lowest (Fig. 8). The oligohaline group $(\mathrm{O})$ was mainly characterised by high densities of naidids (Fig. 8). The $\mathrm{M}$ group was almost completely dominated by chironomids (Fig. 8), except for low densities of the gastropods Hydrobia acuta and Physa sp., exclusive to this group (Tab. 1). The gastropod Ferrissia wautieri and the damselfly $I$. elegans were also representative of this group, but at lower indicator values. The MM group was characterised by the presence of the polychaete Hediste diversicolor and the crustaceans Gammarus aequicauda and Mesopodopsis slabberi, also exclusive to the group (Tab. 1).

\section{DISCUSSION}

The scarcity of studies providing quantitative data on epiphytic macroinvertebrates associated with Phragmites australis created difficulties in conducting a wide comparison of our results. Mean densities of individuals were generally lower than those reported for shallow lakes on the coast of Valencia, where the same sampling methodology was applied (Sahuquillo et al. 2006). This is probably due to the sampling period: in that study, samples were collected in July, when macroinvertebrate densities are high due to better habitat conditions and macroinvertebrate migration from mud to plants in search of higher quality food (Mason et al. 1975; Kairesalo 1984). In the present study, the highest densities (maximum of 32,960 individuals $\mathrm{m}^{-2}$ ) were recorded in summer, nearly equaling those reported by Sahuquillo et al. (2006), who recorded a maximum of 39,000 individuals $\mathrm{m}^{-2}$. The other peak of epiphytic macroinvertebrate density occurred in winter and may be related to high diatom densities and detritus accumulation (EPOM was higher in winter $(54,608 \pm$ $\left.27,381 \mathrm{mg} \mathrm{m}^{-2}\right)$ and autumn $\left(64,735 \pm 15,434 \mathrm{mg} \mathrm{m}^{-2}\right)$ than in spring $\left.\left(20,137 \pm 11,234 \mathrm{mg} \mathrm{m}^{-2}\right)\right)$, which may 
Water chemistry

Conductivity $\left(\mathrm{mS} \mathrm{cm}^{-1}\right)$

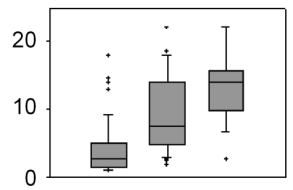

Nutrients (mg L ${ }^{-1}$ )

SRP

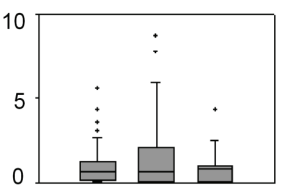

Epiphyton

$\left(\mathrm{g} \mathrm{m}^{-2}\right)$
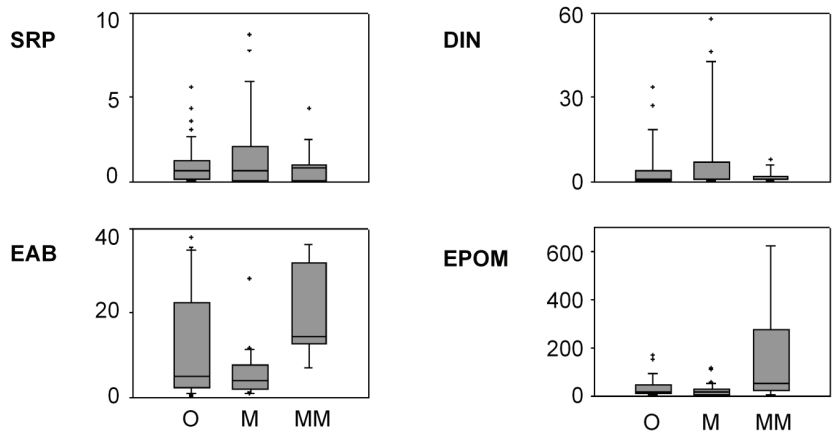

EPOM

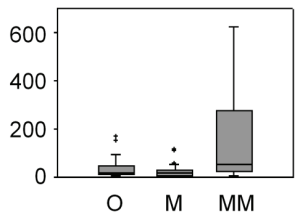

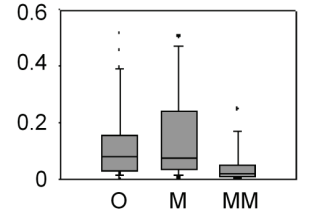

Chironomidae + Gasteropoda

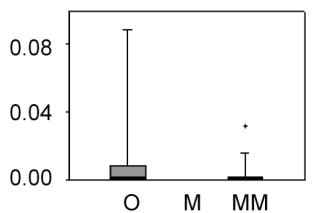

Naididae

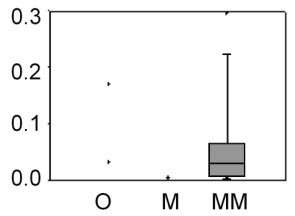

Crustacea + Polychaeta

Fig. 8. Quantification of main elements studied in the epiphytic compartment showed in the idealized scheme from figure 1 (see text for explanation). Box-Plots of the most significant environmental factors, epiphytic algae and organic matter biomasses and epiphytic macroinvertebrates' biomasses for the defined site groups in the cluster analysis (see figure 7 for explanation).

Tab. 1: Indicator values and relative abundance of the taxa for each of the groups defined by cluster analysis. IV $=$ indicator value. $\rho=$ significance of the analysis. Only taxa with $\rho \leq 0.5$ are shown.

\begin{tabular}{|c|c|c|c|c|c|c|}
\hline & & \multirow[b]{2}{*}{ IV } & \multirow[b]{2}{*}{$\rho$} & \multicolumn{3}{|c|}{ Relative abundances (\%) } \\
\hline & & & & $\mathrm{O}$ & $\mathrm{M}$ & $\mathrm{MM}$ \\
\hline \multirow{4}{*}{ Oligohaline $(\mathrm{O})$} & |Naididae & 52.5 & 0.122 & 69 & 1 & 30 \\
\hline & Cricotopus intersectus & 23.5 & 0.085 & 100 & 0 & 0 \\
\hline & Ferrissia wautieri & 17.6 & 0.098 & 100 & 0 & 0 \\
\hline & Limnophyes sp. & 11.8 & 0.299 & 100 & 0 & 0 \\
\hline \multirow{7}{*}{$\begin{array}{l}\text { Mesohaline without direct } \\
\text { connection to the sea (M) }\end{array}$} & Cricotopus sylvestris & 61.3 & 0.148 & 15 & 85 & 0 \\
\hline & Cricotopus ornatus & 49.1 & 0.089 & 4 & 68 & 28 \\
\hline & Chironomus riparius & 48.5 & 0.040 & 24 & 73 & 3 \\
\hline & Cricotopus tricinctus/trifasciatus & 23.5 & 0.085 & 4 & 91 & 5 \\
\hline & Ischnura elegans & 22.2 & 0.118 & 0 & 100 & 0 \\
\hline & Ablabesmyia monilis & 21.1 & 0.157 & 0 & 95 & 5 \\
\hline & Physella acuta & 16.7 & 0.156 & 0 & 100 & 0 \\
\hline \multirow{4}{*}{$\begin{array}{l}\text { Mesohaline with direct } \\
\text { connection to the sea (MM) }\end{array}$} & Gammarus aequicauda & 83.2 & 0.001 & 0 & 0 & 100 \\
\hline & Hediste diversicolor & 66.7 & 0.001 & 0 & 0 & 100 \\
\hline & Dicrotendipes pallidicornis & 37.9 & 0.116 & 11 & 51 & 38 \\
\hline & Mesopodopsis slabberi & 16.7 & 0.150 & 0 & 0 & 100 \\
\hline
\end{tabular}

promote the presence of naidids (Löhlein 1996). The seasonal differences between communities were relevant and statistically significant, but it must be considered that they may be influenced by artificial freshwater inputs (which are very significant in these highly anthropized systems). These water inputs may induce changes in the macroinvertebrate communities through fluctuations in the water level (Balcombe et al. 2007) and, more importantly, through changes in salinity and nutrient content.
No statistically significant differences were recorded between sample replicas with different sun exposure within each lagoon. The hypothesis of sun exposure indirectly influencing the macroinvertebrate community by enhancing algal growth can therefore be rejected. Under extreme experimental conditions, light exposure is known to affect community composition and grazing potential (Wellnitz et al. 1998; Bourassa et al. 2000), but in natural systems these conditions are rarely found and this influence is probably negligible. The influence 
of light on epiphytic communities under natural conditions is likely restricted to a seasonal scale, since the joint effect of light and temperature has been proven to alter epiphytic algae species composition and affect epiphytic macroinvertebrate communities (Albay et al. 2002).

\subsection{Tolerance ranges and species assemblages}

The epiphytic macroinvertebrate communities studied clearly responded to the influence of environmental factors. As reported in previous studies (Arnold et al. 1997; Sahuquillo et al. 2006) the strongest influence on epiphytic macroinvertebrate communities was exerted by salinity and nutrients, with the former having the greatest influence. Salinity is known to restrict the survival of many macroinvertebrate species in relation to the energetic cost of osmoregulation and the suitability of conditions for egg hatching (Williams et al. 1998; Kefford et al. 2007). In the case of chironomids, Pinder (2005) had already demonstrated the importance of salinity to explain their distribution, and Verschuren et al. (2004) were able to use fossil midge composition to reconstruct past salinity conditions in African lakes across a range of conductivities from 20 to $40,000 \mu \mathrm{S}$ $\mathrm{cm}^{-1}$.

Results for optima and tolerances, RDA and IndVal analysis allowed us to register a substitution of species based on the two principal environmental gradients: salinity and eutrophy. In the less eutrophic sites, at low salinities the epiphytic community was mainly characterised by a high diversity of chironomids. Moving towards higher salinities, the community shifted: it was characterised by the presence of gastropods and some euryhaline chironomid species. Finally, under the most saline conditions, the community was dominated by crustaceans and polychaetes. Under hypereutrophic conditions, the community was first dominated by naidids and some pollution-tolerant chironomid species as Cr. sylvestris or Parachironomus. At higher salinities, the chironomids Chironomus riparius and $\mathrm{Cr}$. ornatus clearly dominated the assemblage. These trends are related to restrictions imposed by salinity (as explained above) and ammonium and phosphate toxicity (Armitage et al. 1995). The most euryhaline species were the polychaete Nereis diversicolor, which is known to live under a wide range of salinity conditions (Scaps 2002), and the chironomids Cr. (I.) ornatus and Dicrotendipes pallidicornis, which are considered halobionts (Hirvenoja 1973; ContrerasLichtenberg 1986). A high tolerance for organic pollution was exhibited by the chironomid species of the genus Cricotopus (C. (I.) sylvestris, and C. (I.) tricinctus/trifasciatus) and Ch. riparius, which are known to be pollution-tolerant taxa (Hirvenoja 1973; Wilson et al. 2005).

Water salinity and the causal existence of a direct connection with the sea drove differences between spe- cies assemblages. As shown above, high salinity values limited the survivorship of many taxa, which were only recorded in the oligohaline sites. The existence of a direct connection with the sea was a requirement for brackish-water species to become established. This fact is probably linked to the limited dispersal abilities of these organisms (Cognetti et al. 2000; Josefon et al. 2004). The brackish-water species were exclusive to the MM group, and their presence seemed to have a negative effect on other taxa, which were recorded at much lower densities in sites of this type. This could be related to competition for habitat and food, and to direct predation by the species Mesopodopsis slabberi (Sardo et al. 2005) and Nereis diversicolor (Rön et al. 1988; Scaps 2002) on other epiphytic macroinvertebrates.

\subsection{Variability of elements in the epiphytic compartment}

In the present study, the epiphytic compartment model was simplified by choosing a single host plant and exclusively studying its associated biota, while omitting other elements (meiobenthos, fish, amphibians, and birds) that could be an interesting topic for further research. In this context, the contour of environmental conditions (water chemistry and nutrients) exhibited a higher influence on the epiphytic macroinvertebrate community than on epiphyton biomass (epiphytic algae biomass and particulate organic matter). The biological elements of the epiphytic compartment showed quantitative and compositional differences among the three types of lagoons defined in the transitional water system of the Llobregat Delta. This variability is summarized in figure 8. Epiphyton biomasses (algae and organic matter) were relatively lower in $\mathrm{M}$, in spite of high nutrient levels that should enhance algal growth. This may be related to the relatively higher chironomid and gastropod densities recorded, as these organisms are known to consume fresh algae preferentially (Mason et al. 1975; Lodge 1985; Brönmark 1989; Kornijów et al. 1990 Hann 1991; Botts 1993; Cattaneo et al. 1998; Wetzel 2005). This suggests that grazing pressure on epiphyton by chironomids and gastropods may be the main factor controlling its growth, at least in mesotrophic and eutrophic environments. Nevertheless, other factors, such as competition between phytoplankton (phytoplanktonic chlorophyll- $a$ concentrations in this group were twice as high as in the other groups) and epiphytic algae for light (Scheffer 2004), could also be responsible for the lower EAB and EPOM biomass registered. The highest epiphyton biomasses were recorded in MM. This could be linked to the relatively lower densities of chironomids and gastropods found in this group of sites, which were dominated by crustaceans and polychaetes. These taxa exerted a lower grazing pressure over the epiphyton than was exerted by chironomids and gastropods, as they prefer different foods, such as small animals and detritus (Barnes 1995; Löhlein 1996; Tachet et 
al. 2000; Scaps 2002; Sardo et al. 2005). In the oligohaline group $(\mathrm{O})$, a relatively medium-high epiphytic algae biomass was recorded in spite of the relatively higher naidid densities. This provides evidence of the omnivorous behaviour of this taxon (Löhlein 1996), which seems to feed mainly on dead material (unlike EAB biomass, EPOM biomass was relatively low).

\section{CONCLUSIONS}

In conclusion, it can be stated that the epiphytic macroinvertebrate communities have different structural properties (species composition, density and biomass) depending on a combination of environmental factors, of which salinity and trophic state were observed to have the greatest effect. Moreover, different functional and biologically controlled relationships among the elements of the epiphytic compartment seemed to prevail in each lagoon type. Although chironomids were commonly the most abundant group in all the lagoons, each type of lagoon had its own characteristic species assemblage. Our findings suggest that epiphytic communities may be suitable for characterizing lentic ecosystems, at least in coastal lagoons. This was previously suggested within the ECOFRAME project (Moss et al. 2003), where the same methodology was used; but results from that study were not satisfactory. A higher taxonomic resolution and the inclusion of reference sites for each transitional water type in the data set would be necessary to develop an applicable index; however, this was outside the scope of the present study.

\section{ACKNOWLEDGEMENTS}

This project was financed by the Generalitat de Catalunya. We would like to thank the Consorci del Delta del Llobregat and Taller d'Enginyeria Ambiental for providing us with logistical support. In addition, we would like to thank Roser Farrés for her assistance with field work. Taxonomical advice was provided by V. Bros for Gasteropoda, and Dr. D. Martín for Polychaeta. Some UB undergraduate Biology students also helped in the laboratory. This work was presented as an oral communication at the VII SEFS meeting at Palermo (Italy) in 2007, where it was recognized as one of the best student oral presentations to M.C-A.

\section{REFERENCES}

Albay M. \& G. Aykulu. 2002. Invertebrate grazer - epiphytic algae interactions on submerged macrophytes in a mesotrophic Turkish lake. E.U. Journal of Fisheries and Aquatic Sciences, 19: 247-258.

Armitage, P.D., P.S. Cranston \& L.C.V. Pinder. 1995. The Chironomidae: Biology and Ecology of Non-biting Midges. Chapman \& Hall, London: 572 pp.

Arnold, S.L. \& S.J. Ormerod. 1997. Aquatic macroinvertebrates and environmental gradients in Phragmites reedswamps: implications for conservation. Aquatic Conservation: Marine and Freshwater Ecosystems, 7: 153-163.

Balcombe, S.R., G.P. Closs \& P.J. Suter. 2007. Density and distribution of epiphytic invertebrates on emergent macro- phytes in a floodplain billabong. River Research and Applications, 23: 843-857.

Barnes, R.S.K., 1995. Brackish-Water Fauna of Northwestern Europe. Cambridge University Press., Cambridge: 303 pp.

Batzer, D., R. Rader \& S. Wissinger. 1999. Invertebrates in Freshwater Wetlands of North America: Ecology and Management. John Wiley and Sons: 1120 pp.

Bedford, A.P. \& I. Powell. 2005. Long-Term Changes in the Invertebrates Associated with the Litter of Phragmites australis in a Managed Reedbed. Hydrobiologia, 549: 267-285.

Benke, A.C. 1996. Secondary Production of Macroinvertebrates. In: Hauer \& Lamberti (Eds), Methods in Stream Ecology. Academic Press. Academic Press. Inc, San Diego, U.S.A.: 557-578.

Botts, P. S., 1993. The impact of small chironomid grazers on epiphytic algal abundance and dispersion. Freshwat. Biol., 30: 25-33.

Botts, P.S. \& B.C. Cowell. 1993. Temporal Patterns of Abundance of Epiphytic Invertebrates on Typha Shoots in a Subtropical Lake. Journal of the North American Benthological Society, 12: 27-39.

Bourassa, N. \& A. Cattaneo. 2000. Responses of a lake outlet community to light and nutrient manipulation: effects on periphyton and invertebrate biomass and composition. Freshwat. Biol., 44: 629-639.

Brönmark, C. 1989. Interactions between epiphytes, macrophytes and freshwater snails: a review. Journal of Molluscan Studies, 55: 299-311.

Cabello, P. \& E. Ramos. 2007. 3D modelling of grain size distribution in Quaternary deltaic deposits (Llobregat Delta, NE Spain). Geologica Acta, 5: 231-244.

Cattaneo, A. 1983. Grazing on epiphytes. Limnol. Oceanogr., 28: $124-132$.

Cattaneo, A., G. Galanti, S. Gentinetta \& A. Susana. 1998. Epiphytic algae and macroinvertebrates on submerged and floating-leaved macrophytes in an Italian lake. Freshwat. Biol., 39: 725-740.

Chambers, R. M., L. A. Meyerson \& K. Saltonstall. 1999. Expansion of Phragmites australis into tidal wetlands of North America. Aquatic Botany, 64: 261-273.

Cognetti, G. \& F. Maltagliati. 2000. Biodiversity and adaptive mechanisms in brackish water fauna. Marine Pollution Bulletin, 40: 7-14.

Contreras-Lichtenberg, R. 1986. Revision der Westpaläarktis verbreiteten Arten des Genus Dicrotendipes Kieffer, 1913 (Diptera, Nematocera, Chironomidae). Annalen des Naturhistorischen Museums in Wien, 88/89: 663-726.

Den Hartog, C., J. Kvet \& H. Sukopp, 1989. Reed. A common species in decline. Aquatic Botany, 35: 1-4.

Dufrêne, M. \& P. Legendre. 1997. Species Assemblages and Indicator Species: The Need for a Flexible Asymmetrical Approach. Ecological Monographs, 67: 345-366.

Hart E. A. \& J. R. Lovvorn, 2003. Algal vs. macrophyte inputs to food webs of inland saline wetlands. Ecology, 84: 33173326.

Greenberg, A. E., L. S. Clesceri \& A. D. Eaton. 1999. Standard methods for the examination of water and wastewater. American Public Health Association: 1220 pp.

Hann, B. J., 1991. Invertebrate grazer-periphyton interactions in a eutrophic marsh pond. Freshwat. Biol., 26: 87-96.

Havens, K.E., T.L. East, A.J. Rodusky \& B. Sharfstein. 1999. Littoral periphyton responses to nitrogen and phosphorus: an experimental study in a subtropical lake. Aquatic Botany, 63: 267-290.

Hirvenoja, M., 1973. Revision der Gattung Cricotopus van. der Wulp und ihrer Verwandten (Diptera, Chironomidae). Annales Zoologici Fennici, 10: 257-304.

Jayawardana, J., M. Westbrooke, M. Wilson \& C. Hurst. 2006. Macroinvertebrate communities in Phragmites australis (Cav.) Trin. ex Steud. reed beds and open bank 
habitats in central victorian streams in Australia. Hydrobiologia, 568: 169-185.

Jones, J.I., J.O. Young, J.W. Eaton \& B. Moss. 2002. The influence of nutrient loading, dissolved inorganic carbon and higher trophic levels on the interaction between submerged plants and periphyton. J. Ecol., 90: 12-24.

Josefon, A.B. \& J.L.S. Hansen. 2004. Species richness of benthic macrofauna in Danish estuaries and coastal areas. Global Ecology and Biogeography, 13: 273-288.

Juggins, S. 2005. C2 data analysis. University of Newcastle. http://www.staff.ncl.ac.uk/staff/stephen.juggins/software.htm

Kairesalo, T. 1984. The seasonal succession of epiphytic communities within an Equisetum fluviatile L. stand in Lake Pääjärvi, southern Finland. Internationale Revue der Gesamten Hydrobiologie, 69: 475-505.

Kefford, B., D. Nugegoda, L. Zalizniak, E. Fields \& K. Hassell. 2007. The salinity tolerance of freshwater macroinvertebrate eggs and hatchlings in comparison to their older life-stages: a diversity of responses. Aquatic Ecology, 41: 335-348.

Kornijów, R. \& R. Gulati. 1992. Macrofauna and its ecology in Lake Zwemlust, after biomanipulation. II. Fauna inhabiting hydrophytes. Arch. Hydrobiol., 123: 349-359.

Kornijów, R. \& T. Kairesalo. 1994. A simple apparatus for sampling epiphytic communities associated with emergent macrophytes. Hydrobiologia, 294: 141-143.

Kornijów, R., R. Gulati \& E. van Donk. 1990. Hydrophytemacroinvertebrate interactions in Zwemlust, a lake undergoing biomanipulation. Hydrobiologia, 200-201: 467-474.

Legendre, P. \& L. Legendre. 1998. Numerical ecology. Elsevier Science, Amsterdam: 853 pp.

Lepš, J. \& P. Šmilauer. 2003. Multivariate Analysis of Ecological Data Using CANOCO. Cambridge University Press, Cambridge: 269 pp.

Liboriussen, L. 2003. Production, regulation and ecophysiology of periphyton in shallow freshwater lakes. Institute of Biological Sciences. University of Aarhus: 47.

Liu, Q. 1997. Variation partitioning by partial redundancy analysis (RDA). Environmetrics, 8: 75-85.

Lodge, D.M. 1985. Macrophyte-gastropod associations: observations and experiments on macrophyte choice by gastropods. Freshwat. Biol., 15: 695-708.

Löhlein, B., 1996. Seasonal dynamics of aufwuchs Naididae (Oligochaeta) on Phragmites australis in a eutrophic lake. Hydrobiologia, 334: 115-123.

Lucena, J.R., J. Hurtado \& F. Comín, 2002. Nutrients related to the hydrologic regime in the coastal lagoons of Viladecans (NE Spain). Hydrobiologia, 475-476.

Maberly, S. C., L. King, M. M. Dent, R. I. Jones \& C. E. Gibson, 2002. Nutrient limitation of phytoplankton and periphyton growth in upland lakes. Freshwat. Biol., 47: 2136-2152.

Mason, C. F. \& R. J. Bryant, 1975. Periphyton production and grazing by chironomids in Alderfen Broad, Norfolk. Freshwat. Biol., 5: 271-277.

McCune, B. \& J. Mefford. 1999. PCORD: Multivariate Analysis of Ecological Data. MjM software, Oregon.

Moss, B., D. Stephen, C. Alvarez, E. Becares, W.V.D. Bund, S.E. Collings, E.V. Donk, E.D. Eyto, T. Feldmann, C. Fernández-Aláez, M. Fernández-Aláez, R.J.M. Franken, F. García-Criado, E.M. Gross, M. Gyllström, L.-A. Hansson, K. Irvine, A. Järvalt, J.-P. Jensen, E. Jeppesen, T. Kairesalo, R. Kornijów, T. Krause, H. Künnap, A. Laas, E. Lill, B. Lorens, H. Luup, M.R. Miracle, P. Nõges, T. Nõges, M. Nykänen, I. Ott, W. Peczula, E. Peeters, G. Phillips, S. Romo, V. Russell, J. Salujõe, M. Scheffer, K. Siewertsen, H. Smal, C. Tesch, H. Timm, L. Tuvikene, I. Tonno, T. Virro, E. Vicente \& D. Wilson. 2003. The determination of ecological status in shallow lakes - a tested system (ECOFRAME) for implementation of the European Water
Framework Directive. Aquatic Conservation: Marine and Freshwater Ecosystems, 13: 507-549.

Müller, U. 1995. Vertical zonation and production rates of epiphytic algae on Phragmites australis. Freshwat. Biol., 34: 69-80.

Pan, Y., R.J. Stevenson, P. Vaithiyanathan, J. Slate \& C.J. Richardson. 2000. Changes in algal assemblages along observed and experimental phosphorus gradients in a subtropical wetland, U.S.A. Freshwat. Biol., 44: 339-353.

Papas, P. 2007. Effect of macrophytes on aquatic invertebrates - a literature review. In: Research, A.R.I.f.E. (Ed.), Technical Report Series 158. Arthur Rylah Institute Environmental Research: 22.

Pinder, A.M., S.A. Halse, J.M. Mcrae \& R.J. Shiel. 2005. Occurrence of aquatic invertebrates of the wheatbelt region of Western Australia in relation to salinity. Hydrobiologia, 543: 1-24.

Planas, R. 1984. Braços de riu, estanys i maresmes del delta del Llobregat. Caixa d'Estalvis de Catalunya, Barcelona: $133 \mathrm{pp}$.

Prat, N. \& M. Rieradevall. 1995. Life cycle and production of Chironomidae (Diptera) from Lake Banyoles (NE Spain). Freshwat. Biol., 33: 511-524.

Rön, C., E. Bonsdorff \& W.G. Nelson. 1988. Predation as a mechanism of interference within infauna in shallow brackish water soft bottoms; experiments with an infauna predator, Nereis diversicolor O.F. Müller. Journal of Experimental Marine Biology and Ecology, 116: 143-157.

Rooke, J.B. 1984. The invertebrate fauna of four macrophytes in a lotic system. Freshwat. Biol., 14: 507-513.

Sahuquillo, M., M.R. Miracle \& M. Rieradevall, 2006. Macroinvertebrates associated with reed stems. Verh. int. Ver. Limnol., 29: 2245-2246.

Sahuquillo, M., J.M. Poquet, J. Rueda \& M.R. Miracle. 2007. Macroinvertebrate communities in sediment and plants in coastal Mediterranean water bodies (Central Iberian Peninsula). Annales Limnologie - International Journal of Limnology, 43: 117-130.

Sardo, A.M., F. Morgado \& A. Soares. 2005. Mesopodopsis slabberi (Crustacea: Mysidacea): can it be used in toxicity tests? Ecotoxicology and environmental safety, 60: 81-86.

Scaps, P., 2002. A review of the biology, ecology and potential use of the common ragworm Hediste diversicolor (O.F. Müller) (Annelida: Polychaeta). Hydrobiologia, 470: 203-218.

Scheffer, M., 2004. Ecology of shallow lakes. Kluwer Academic Publishers, Dordrecht: 357 pp.

Schnell Ø., M. Rieradevall, I. Granados \& O. Hanssen. 1999. A chironomid taxa coding system for use in ecological and paleoecological databases. NIVA-Report No $\mathrm{N}^{\mathrm{o}} 3710-97$, MOLAR Project Manual, Annex B: 19 pp.

Tachet, H., P. Richoux, M. Ournaud \& P. Usseglio-Polatera. 2000. Invertébrés d'eau douce: Systématique, biologie, écologie. CNRS Editions, Paris: 588 pp.

Taniguchi, H., S. Nakano \& M. Tokeshi. 2003. Influences of habitat complexity on the diversity and abundance of epiphytic invertebrates on plants. Freshwat. Biol., 48: 718-728.

Urban, E. 1975. The Mining Fauna in Four Macrophyte Species in Mikolajskie Lake. Ekologia Polska, 23: 417-435.

Verschuren, D., B.F. Cumming \& K.R. Laird. 2004. Quantitative reconstruction of past salinity variations in African lakes: assessment of chironomid-based inference models (Insecta: Diptera) in space and time. Can. J. Fish. Aquat. Sci., 61: 986-998.

Wellnitz, T. A. \& J.V. Ward. 1998. Does light intensity modify the effect mayfly grazers have on periphyton? Freshwat. Biol., 39: 135-149.

Wetzel, R.G. 1983. Opening remarks. In: Wetzel, R.G. (Ed.), Periphyton of Freshwater Ecosystems. Dr W. Junk Publishers, The Hague. 
Wetzel, R.G. 2005. Periphyton: Ecology, Exploitation and Managment. In: Azim, M.E., M. Verdegem, A. v. Dam \& M. Beveridge (Eds), Periphyton in the Aquatic Ecosystem and Food Webs. CABI Publishing, Wallingford: 51-66.

Williams, D.D. \& N.E. Williams. 1998. Aquatic insects in an estuarine environment: densities, distribution and salinity tolerance. Freshwat. Biol., 39: 411-421.
Wilson, R.S. \& L. Ruse. 2005. A guide to the identification of genera of chironomid pupal exuviae occurring in Britain and Ireland. Freshwater Biological Association, Cumbria: $176 \mathrm{pp}$.

\section{A P P E N D I X}

Densities ( \pm standard deviation) of recorded taxa in each water body.

\begin{tabular}{|c|c|c|c|c|c|c|c|c|c|c|c|c|}
\hline & Code & EB11 & EB10 & EB7 & $\mathrm{RE}$ & EB8 & CT & EB6 & CA & EB5 & RI & EB9 \\
\hline F. Naididae & Naid & $\begin{array}{c}4295 \\
( \pm 4295)\end{array}$ & $\begin{array}{c}2 \\
( \pm 2)\end{array}$ & $\begin{array}{c}58 \\
( \pm 31)\end{array}$ & $\begin{array}{c}2345 \\
( \pm 2318)\end{array}$ & $\begin{array}{c}390 \\
( \pm 179)\end{array}$ & $\begin{array}{c}4 \\
( \pm 4)\end{array}$ & $\begin{array}{c}108 \\
( \pm 100)\end{array}$ & $\begin{array}{c}75 \\
( \pm 66)\end{array}$ & $\begin{array}{c}27 \\
( \pm 25)\end{array}$ & $\begin{array}{c}487 \\
( \pm 482)\end{array}$ & $\begin{array}{c}6 \\
( \pm 6)\end{array}$ \\
\hline \multicolumn{13}{|l|}{ Polychaeta } \\
\hline Hediste diversicolor (Müller, 1776) & Hedi & 0 & 0 & 0 & 0 & 0 & 0 & $\begin{array}{c}65 \\
( \pm 58)\end{array}$ & 0 & 0 & $\begin{array}{c}30 \\
( \pm 20)\end{array}$ & 0 \\
\hline \multicolumn{13}{|l|}{ Gasteropoda } \\
\hline Ferrissia wauteri (Mirolli, 1960) & Ferris & $\begin{array}{c}13 \\
( \pm 12)\end{array}$ & 0 & 0 & 0 & $\begin{array}{c}5 \\
( \pm 5)\end{array}$ & 0 & 0 & 0 & 0 & 0 & 0 \\
\hline Hydrobia acuta (Draparnaud, 1805) & Hydrob & 0 & 0 & 0 & 0 & $\begin{array}{c}2 \\
( \pm 2)\end{array}$ & 0 & $\begin{array}{c}10 \\
( \pm 10)\end{array}$ & $\begin{array}{c}59 \\
( \pm 59)\end{array}$ & 0 & 0 & 0 \\
\hline Physella acuta (Draparnaud, 1805) & Phys & 0 & 0 & 0 & 0 & $\begin{array}{c}2 \\
( \pm 2)\end{array}$ & $\begin{array}{c}13 \\
( \pm 13)\end{array}$ & $\begin{array}{c}6 \\
( \pm 6)\end{array}$ & 0 & 0 & 0 & $\begin{array}{c}6 \\
( \pm 6)\end{array}$ \\
\hline \multicolumn{13}{|l|}{ Crustacea } \\
\hline Corophium insidiosum Crawford, 1937 & Corop & 0 & 0 & 0 & 0 & 0 & 0 & 0 & $\begin{array}{c}350 \\
( \pm 348)\end{array}$ & 0 & 0 & 0 \\
\hline Gammarus aequicauda (Martynov, 1931) & Gamm & $\begin{array}{c}1 \\
( \pm 1)\end{array}$ & 0 & 0 & 0 & 0 & 0 & $\begin{array}{c}193 \\
( \pm 190)\end{array}$ & 0 & 0 & $\begin{array}{c}361 \\
( \pm 349)\end{array}$ & 0 \\
\hline Mesopodopsis slabberi (Van beneden, 1861) & Meso & 0 & 0 & $\begin{array}{c}29 \\
( \pm 28)\end{array}$ & 0 & 0 & 0 & $\begin{array}{c}3 \\
( \pm 3)\end{array}$ & 0 & 0 & $\begin{array}{c}28 \\
( \pm 28)\end{array}$ & 0 \\
\hline Orchestia gammarellus (Pallas, 1766) & Orch & 0 & 0 & $\begin{array}{c}2 \\
( \pm 2)\end{array}$ & 0 & 0 & 0 & 0 & 0 & 0 & 0 & 0 \\
\hline Palaemon elegans Rathke, 1837 & Pala & 0 & 0 & 0 & 0 & 0 & 0 & $\begin{array}{c}2 \\
( \pm 2)\end{array}$ & 0 & 0 & 0 & 0 \\
\hline \multicolumn{13}{|l|}{ Coleoptera } \\
\hline F. Elmidae & Elmi & 0 & 0 & 0 & 0 & 0 & 0 & 0 & 0 & 0 & 0 & $\begin{array}{c}3 \\
( \pm 3)\end{array}$ \\
\hline Haliplus Latreille, 1802 & Hali & 0 & 0 & 0 & 0 & 0 & 0 & 0 & 0 & $\begin{array}{c}3 \\
( \pm 3)\end{array}$ & 0 & 0 \\
\hline Hydrovatus Motschulsky, 1853 & Hydrov & 0 & 0 & 0 & 0 & 0 & 0 & 0 & 0 & $\begin{array}{c}16 \\
( \pm 16)\end{array}$ & 0 & 0 \\
\hline Hydroglyphus Motschulsky, 1853 & Hydrog & 0 & $\begin{array}{c}2 \\
( \pm 2)\end{array}$ & 0 & 0 & 0 & 0 & 0 & 0 & 3 & 0 & 0 \\
\hline \multicolumn{13}{|l|}{ Odonata } \\
\hline Ischnura elegans (Vander Linden, 1820) & Isch & 0 & 0 & $\begin{array}{c}11 \\
( \pm 11)\end{array}$ & $\begin{array}{c}1 \\
( \pm 1)\end{array}$ & 0 & $\begin{array}{c}1 \\
( \pm 1)\end{array}$ & 0 & 0 & $\begin{array}{c}5 \\
( \pm 5)\end{array}$ & 0 & $\begin{array}{c}6 \\
( \pm 6)\end{array}$ \\
\hline \multicolumn{13}{|l|}{ Ephemeroptera } \\
\hline Cloeon cognatum STEPHENS, 1835 & Cloe & 0 & 0 & 0 & 0 & $\begin{array}{c}2 \\
( \pm 2)\end{array}$ & 0 & 0 & 0 & 0 & 0 & 0 \\
\hline \multicolumn{13}{|l|}{ Diptera } \\
\hline F. Ceratopogonidae & Cera & 0 & 0 & 0 & 0 & 0 & 0 & 0 & $\begin{array}{c}9 \\
( \pm 9)\end{array}$ & $\begin{array}{c}5 \\
( \pm 5)\end{array}$ & 0 & 0 \\
\hline F. Empididae & Empi & $\begin{array}{c}1 \\
( \pm 1)\end{array}$ & 0 & 0 & 0 & 0 & 0 & 0 & 0 & 0 & 0 & 0 \\
\hline F. Limoniidae & Limón & 0 & 0 & 0 & 0 & 0 & 0 & 0 & 0 & 0 & 0 & $\begin{array}{c}2 \\
( \pm 2)\end{array}$ \\
\hline \multicolumn{13}{|l|}{ F. Chironomidae } \\
\hline Ablabesmyia monilis (Linnaeus, 1758) & Abla mon & 0 & 0 & 0 & 0 & 0 & $\begin{array}{c}69 \\
( \pm 52)\end{array}$ & $\begin{array}{c}1 \\
( \pm 1)\end{array}$ & 0 & $\begin{array}{c}6 \\
( \pm 5)\end{array}$ & 0 & $\begin{array}{c}194 \\
( \pm 192)\end{array}$ \\
\hline Chironomus riparius (Meigen, 1804) & Chir rip & $\begin{array}{c}3 \\
( \pm 3)\end{array}$ & $\begin{array}{c}639 \\
( \pm 367)\end{array}$ & $\begin{array}{c}5 \\
( \pm 5)\end{array}$ & $\begin{array}{c}656 \\
( \pm 369)\end{array}$ & 0 & 0 & $\begin{array}{c}1145 \\
( \pm 1062)\end{array}$ & $\begin{array}{c}13 \\
( \pm 13)\end{array}$ & $\begin{array}{c}488 \\
( \pm 243)\end{array}$ & $\begin{array}{c}10 \\
( \pm 10)\end{array}$ & $\begin{array}{c}292 \\
( \pm 169)\end{array}$ \\
\hline Corynoneura scutellata Winnertz, 1846 & Cory scu & $\begin{array}{c}3 \\
( \pm 4)\end{array}$ & 0 & 0 & 0 & 0 & 0 & 0 & 0 & 0 & 0 & 0 \\
\hline
\end{tabular}


Tab. Appendix. Continuation

\begin{tabular}{|c|c|c|c|c|c|c|c|c|c|c|c|c|}
\hline & Code & EB11 & EB10 & EB7 & $\mathrm{RE}$ & EB8 & CT & EB6 & $\mathrm{CA}$ & EB5 & RI & EB9 \\
\hline Cricotopus (I.) intersectus (Staeger, 1839) & Cric int & 0 & 0 & $\begin{array}{c}283 \\
( \pm 151)\end{array}$ & 0 & $\begin{array}{c}748 \\
( \pm 232)\end{array}$ & 0 & 0 & 0 & 0 & 0 & 0 \\
\hline Cricotopus (I.) ornatus (Meigen, 1818) & Cric orn & 0 & 0 & $\begin{array}{c}37 \\
( \pm 24)\end{array}$ & $\begin{array}{c}1638 \\
( \pm 1313)\end{array}$ & 0 & $\begin{array}{c}5 \\
( \pm 5)\end{array}$ & $\begin{array}{c}380 \\
( \pm 289)\end{array}$ & $\begin{array}{c}181 \\
( \pm 94)\end{array}$ & $\begin{array}{c}469 \\
( \pm 203)\end{array}$ & $\begin{array}{c}264 \\
( \pm 217)\end{array}$ & $\begin{array}{c}754 \\
( \pm 662)\end{array}$ \\
\hline Cricotopus (I.) sylvestris (Fabricius, 1794) & Cric syl & $\begin{array}{c}913 \\
( \pm 859)\end{array}$ & $\begin{array}{c}119 \\
( \pm 100)\end{array}$ & $\begin{array}{c}267 \\
( \pm 87)\end{array}$ & $\begin{array}{c}5437 \\
( \pm 5161)\end{array}$ & $\begin{array}{c}131 \\
( \pm 68)\end{array}$ & $\begin{array}{c}70 \\
( \pm 70)\end{array}$ & $\begin{array}{c}862 \\
( \pm 845)\end{array}$ & 0 & $\begin{array}{c}840 \\
( \pm 510)\end{array}$ & 0 & $\begin{array}{c}1075 \\
( \pm 1009)\end{array}$ \\
\hline Cricotopus (I.) tricinctus/trifasciatus & Cric trc & 0 & 0 & $\begin{array}{c}12 \\
( \pm 12)\end{array}$ & $\begin{array}{c}344 \\
( \pm 344)\end{array}$ & 0 & 0 & $\begin{array}{c}178 \\
( \pm 178)\end{array}$ & 0 & 0 & 0 & $\begin{array}{c}21 \\
( \pm 21)\end{array}$ \\
\hline $\begin{array}{l}\text { Dicrotendipes pallidicornis (Goetghebuer } \\
\text { 1934) }\end{array}$ & Dicr pal & 0 & 0 & 0 & $\begin{array}{c}12 \\
( \pm 12)\end{array}$ & $\begin{array}{c}28 \\
( \pm 28)\end{array}$ & $\begin{array}{c}476 \\
( \pm 204)\end{array}$ & $\begin{array}{c}198 \\
( \pm 178)\end{array}$ & $\begin{array}{c}264 \\
( \pm 195)\end{array}$ & $\begin{array}{c}612 \\
( \pm 445)\end{array}$ & $\begin{array}{c}96 \\
( \pm 77)\end{array}$ & 0 \\
\hline Glyptotendipes pallens (Meigen, 1804) & Glyp pal & 0 & 0 & $\begin{array}{c}7 \\
( \pm 7)\end{array}$ & 0 & 0 & 0 & 0 & 0 & 0 & 0 & 0 \\
\hline $\begin{array}{l}\text { Kiefferulus tendipediformis (Goetghebuer, } \\
\text { 1921) }\end{array}$ & Kief ten & $\begin{array}{c}43 \\
( \pm 43)\end{array}$ & 0 & 0 & 0 & 0 & 0 & 0 & 0 & 0 & 0 & 0 \\
\hline Limnophyes indet. & Limnind & $\begin{array}{c}3 \\
( \pm 3)\end{array}$ & 0 & 0 & 0 & $\begin{array}{c}24 \\
( \pm 24)\end{array}$ & 0 & 0 & 0 & 0 & 0 & 0 \\
\hline Parachironomus Lenz, 1921 & Parcind & 0 & 0 & 0 & $\begin{array}{c}13 \\
( \pm 13)\end{array}$ & $\begin{array}{c}27 \\
( \pm 17)\end{array}$ & 0 & 0 & 0 & 0 & 0 & 0 \\
\hline Paratanytarsus grimmi (Schneider, 1885) & Part gri & $\begin{array}{c}100 \\
( \pm 64)\end{array}$ & 0 & $\begin{array}{c}6 \\
( \pm 6)\end{array}$ & $\begin{array}{c}189 \\
( \pm 189)\end{array}$ & $\begin{array}{c}61 \\
( \pm 61)\end{array}$ & 0 & 0 & 0 & 0 & 0 & 0 \\
\hline $\begin{array}{l}\text { Psectrocladius sordidellus (Zetterstedt, } \\
1838 \text { ) }\end{array}$ & Psec sord & 0 & 0 & $\begin{array}{c}136 \\
( \pm 79)\end{array}$ & 0 & $\begin{array}{c}12 \\
( \pm 12)\end{array}$ & $\begin{array}{c}294 \\
( \pm 219)\end{array}$ & 0 & $\begin{array}{c}281 \\
( \pm 233)\end{array}$ & 0 & 0 & 0 \\
\hline Tanytarsus Van der Wulp, 1874 & Tanyind & 0 & 0 & 0 & 0 & 0 & $\begin{array}{c}21 \\
( \pm 21)\end{array}$ & 0 & 0 & 0 & 0 & 0 \\
\hline Total & & $\begin{array}{c}5375 \\
( \pm 374)\end{array}$ & $\begin{array}{c}762 \\
( \pm 55)\end{array}$ & $\begin{array}{c}853 \\
( \pm 34)\end{array}$ & $\begin{array}{l}10635 \\
( \pm 515)\end{array}$ & $\begin{array}{c}1432 \\
( \pm 171)\end{array}$ & $\begin{array}{c}953 \\
( \pm 47)\end{array}$ & $\begin{array}{c}3151 \\
( \pm 124)\end{array}$ & $\begin{array}{l}1232 \\
( \pm 45)\end{array}$ & $\begin{array}{c}2474 \\
( \pm 101)\end{array}$ & $\begin{array}{c}1276 \\
( \pm 55)\end{array}$ & $\begin{array}{c}2359 \\
( \pm 112)\end{array}$ \\
\hline
\end{tabular}

Received: December 2008

Accepted: April 2009 